Al Qalam: Jurnal Ilmiah Keagamaan dan Kemasyarakatan https://jurnal.stiq-amuntai.ac.id/index.php/al-qalam

P-ISSN: 1907-4174; E-ISSN: 2621-0681

DOI: 10.35931/aq.v14i1.204

\title{
STRATEGI PENYULUH AGAMA DALAM PEMBERDAYAAN MUALLAF KECAMATAN TURI KABUPATEN SLEMAN
}

Oleh:

\author{
Rosidin $^{1}$, Widodo ${ }^{2}$, Siti Aminah ${ }^{3}$ \\ Peneliti Balai Litbang Agama Semarang ${ }^{1}$, Penyuluh Agama KUA Pakem, \\ Kementerian Agama Kab. Sleman ${ }^{2}$, Penyuluh Agama KUA Turi, Kementerian \\ Agama Kab. Sleman ${ }^{3}$ \\ e-mail: nazalnifa@yahoo.co.id ${ }^{1}$ widodoabusayyid@gmail.com², \\ sitiaminahsleman@gmail.com ${ }^{3}$
}

\begin{abstract}
Religious educators has prominent roles on community spiritual development, includes Muslim converts or Mualaf. Converts needs much more guidance to strengthen their faith. Therefore, religious educators should apply appropriate strategies to develop communities in both material and spiritual aspects. This paper tried to explain the strategies were used by religious educators to carry out their functions and the efforts to develop converts in Turi Subdisrict. This study applied qualitative approach. The results of the study were: first, religious educators have already properly conducted their function, includes: informative, educative, consultative, and advocative. Second, Convert empowerment program includes several activities, such as: Convert friendship forum; Faith strengthening and sharia practices; and convert's economic development. Third, Religious educators roled as a bridge between converts and external parties, Regional Amil Zakat Agency (Bazda) of Sleman District and National Amil Zakat (Baznas), Religious Ministry, Religious Community Organization of Sleman District, Pokjaluh, and Regional Government of Sleman District.
\end{abstract}

Keywords: religious educators, roles, function, convert empowerment, Mualla

\begin{abstract}
Abstrak
Penyuluh Agama merupakan garda depan dalam membina spiritual hidup masyarakat, termasuk muallaf, yaitu orang yang baru masuk Islam. Selain
\end{abstract}


Rosidin, Widodo, \& Siti Aminah: Strategi Penyuluh Agama Dalam Pemberdayaan Muallaf Kecamatan Turi Kabupaten Sleman

kebutuhan rohani, muallaf membutuhkan sentuhan lain agar lebih kuat dan berdaya. Dalam tataran ini penyuluh agama perlu implementasi berbagai strategi agar berhasil membina masyarakat, baik ruhaniah maupun jasmaniah. Artikel ini berusaha mengungkap strategi penyuluh Agama dalam melaksanakan fungsi-fungsi dan upaya penyuluh agama Islam dalam memberdayakan Muallaf di Kecamatan Turi. Kajian ini merupakan hasil riset dengan menggunakan pendekatan Kualitatif. Hasil analisis mengungkapkan bahwa: pertama, penyuluh agama sudah berupaya mengembangkan fungsi-fungsi yang dimiliki yaitu fungsi informative, edukatif, konsultatif, dan advokatif. Kedua, program pemberdayaan muallaf yang sudah di jalankan meliputi penguatan kelembagaan dengan membentuk Forum Silaturrahmi Muallaf Kecamatan Turi, penguatan keimanan dan pengamalan ajaran agama Islam, dan program penguatan ekonomi muallaf. Ketiga, Penyuluh Agama Islam menjembatani komunikasi dan sinergi muallaf dengan pihak eksternal, Baznas Sleman dan Pusat, Kementerian Agama, Ormas Keagamaan Sleman, Pokjaluh dan Pemerintah Kabupaten Sleman.

Kata Kunci: Penyuluh Agama Islam, Peran, Fungsi, Pemberdayaan, Muallaf

\section{Pendahuluan}

Agama mempunyai peran strategis sejak belum munculnya peradaban manusia. Selain identitas, agama berperan sebagai norma dan pengatur tingkah laku manusia yang utama karena bersumber dari Tuhan. ${ }^{1}$ Penduduk Indonesia sebagian besar memeluk Agama Islam, termasuk di Sleman. Pemeluk agama Islam di Kecamatan Turi di atas $85 \%$ dari seluruh penduduk Kecamatan Turi. ${ }^{2}$ Pemahaman masyarakat terhadap nilai-nilai dan ajaran Islam masih menjadi tanggung jawab serta kewajiban bersama bagi setiap muslim, ulama dan tokoh agama, serta pemerintah. Dalam hal ini, pemerintah mempunyai Penyuluh Agama, fungsional maupun honorer di Kecamatan Turi.

${ }^{1}$ Rosidin, Indeks Peran Penyuluh Agama dalam Membina Kehidupan Beragama Keluarga Majelis Taklim di Kabupaten Sragen, dalam Jurnal SMART, Vol. 3 No. 1 Juni 2017. (Semarang: Balai Penelitian dan Pengembangan Agama Semarang, 2017). h. 80

${ }^{2}$ BPS Kabupaten Sleman, Kecamatan Turi Dalam Angka Tahun 2017. (Sleman: PT. Solo Grafika Utama), h. 18

Al Qalam: Jurnal Ilmiah Keagamaan dan Kemasyarakatan

Vol. 14, No. 1, Januari-Juni 2020 
Rosidin, Widodo, \& Siti Aminah: Strategi Penyuluh Agama Dalam Pemberdayaan Muallaf Kecamatan Turi Kabupaten Sleman

Tanggung jawab tersebut sebagaimana firman Allah swt dalam QS An Nahl 125:

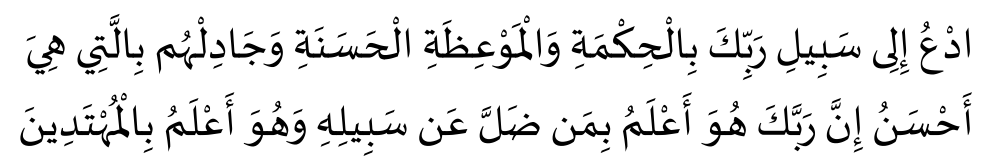

Artinya : Serulah (manusia) kepada jalan Tuhan-mu dengan hikmah dan pelajaran yang baik dan bantahlah mereka dengan cara yang baik. Sesungguhnya Tuhanmu dialah yang lebih mengetahui tentang siapa yang tersesat dari jalan-Nya dan dialah yang lebih mengetahui orang-orang yang mendapat petunjuk ${ }^{3}$ (QS. An Nahl: 125).

Penyuluh agama adalah ujung tombak yang berperan penting dalam upaya membimbing masyarakat memahami ajaran agama dan mengamalkannya. Keberhasilan seorang Penyuluh Agama Islam dalam melaksanakan tugasnya di Kecamatan Turi ditentukan oleh beberapa komponen diantaranya strategi dakwah yang dipilih dan dirumuskan, strategi untuk memberdayakan para muallaf di wilayah Kecamatan Turi serta strategi menghadapi perbedaan latar belakang menjadi seorang Muslim.

Sudah semestinya Penyuluh Agama Islam memahami dan mengetahui kemajemukan masyarakat di wilayah binaannya. Majemuk dalam hal latar belakang keyakinan, agama, tradisi, budaya, pekerjaan, pendidikan serta status sosial ekonomi yang berbeda-beda. Disamping itu banyaknya para muallaf (orang yang berpindah keyakinan dari non Islam masuk Islam) kurang lebih 200 orang muallaf tercatat dari masuk Islam sejak tahun 1999 sampai 2018. Menghadapi kondisi ini seorang penyuluh 1990)

${ }^{3}$ Departemen Agama, Al Qur'an dan Terjemahan. (Jakarta: Departemen Agama, 
Rosidin, Widodo, \& Siti Aminah: Strategi Penyuluh Agama Dalam Pemberdayaan Muallaf Kecamatan Turi Kabupaten Sleman

harus merumuskan program khusus untuk memberikan bimbingan penyuluhan yang tepat kepada para muallaf, sehingga mereka merasakan kenyamanan dalam beragama setelah proses perjalanan ruhani dengan berpindahnya keyakinan. Penyuluh agama tentu semakin tertantang untuk merumuskan berbagai strategi untuk pemberdayaan para muallaf dari penguatan aqidah dan ibadah serta pemberdayaan ekonominya. Maka penyuluh harus menyusun strategi pemberdayaan muallaf yang tepat sehingga pelaksanaan tugas kepenyuluhannya dapat tercapai dengan baik.

Untuk menunjang pelaksanaan tugas Penyuluh Agama, Pemerintah telah mengeluarkan Keppres Nomor 87 Tahun 1999 tentang Rumpun Jabatan Fungsional Pegawai Negeri Sipil yang menyatakan bahwa Penyuluh Agama adalah Jabatan Fungsional Pegawai Negeri yang termasuk dalam rumpun keagamaan. Sedangkan peran dan fungsi penyuluh agama Islam dalam pemberdayaan muallaf mencakup semua langkah yang tepat dalam melaksanakan tugas penyuluhan, menentukan sasaran penyuluhan, menggunakan metode penyuluhan yang tepat sesuai dengan keadaan dan kondisi sasaran. ${ }^{4}$

Beberapa permasalahan muallaf dapat diidentifikasikan sebagai berikut: 1)Kegiatan pembinaan penyuluhan agama belum bisa menjangkau keseluruh wilayah Kecamatan Turi khususnya bagi para muallaf, 2) Sekitar $80 \%$ muallaf belum mampu baca Qur'an dengan baik, 3) Muallaf baru status pindah agama tetapi amaliah agama masih banyak yang belum paham maka perlunya bimbingan penyuluhan agama secara intensif, 4) Kondisi ekonomi muallaf sebagian besar masuk katagori miskin dan sangat membutuhkan suntikan dana untuk menguatkan ekonomi dengan

\footnotetext{
${ }^{4}$ Dokumen Keppres No. 87 Tahun 1999 tentang Rumpun Jabatan Fungsional Pegawai Negeri Sipil
} 
Rosidin, Widodo, \& Siti Aminah: Strategi Penyuluh Agama Dalam Pemberdayaan Muallaf Kecamatan Turi Kabupaten Sleman

modal usaha yang sesuai dengan ketrampilannya, 5) Kegiatan bimbingan agama masih bersifat ibadah ritual seperti mujahadahan, ziarah dan amaliah amaliah dzikir, tetapi kegiatan yang bersifat kajian agama belum maksimal, 6) Semangat untuk belajar agama cukup baik, tetapi sumber daya untuk memberikan materi bimbingan terbatas, dan 7) Kepedulian dan keberpihakan Ormas Islam dan Lembaga Dakwah di wilayah Kecamatan Turi terhadap muallaf Turi belum optimal.

Kajian ini berusaha mengungkap strategi, peran dan program Penyuluh Agama Islam dalam pemberdayaan Muallaf di Kecamatan Turi Kabupaten Sleman.

\title{
KAJIAN PUSTAKA
}

\section{Peran dan Fungsi Penyuluh Agama Islam}

Keputusan Menteri Agama (KMA) Nomor 516 tahun 2003 merupakan landasan kerja Jabatan Penyuluh Agama Fungsional, yaitu melakukan dan mengembangkan kegiatan bimbingan atau penyuluhan agama dan pembangunan melalui bahasa agama kepada masyarakat ${ }^{5}$. Secara lengkap dalam KMA Nomor 79 tahun 1985 disebutkan

\begin{abstract}
"Penyuluh Agama mempunyai peranan sebagai pembimbing masyarakat, sebagai panutan dan sebagai penyambung tugas pemerintah". penyuluh agama Islam mempunyai fungsi yang sangat dominan dalam melaksanakan kegiatannya, yaitu: "Fungsi Informatif dan Edukatif, ialah Penyuluh Agama Islam memposisikan sebagai da'i yang berkewajiban menda'wahkan Islam, menyampaikan penerangan agama dan mendidik masyarakat dengan sebaik-baiknya sesuai ajaran agama. Fungsi Konsultatif, ialah Penyuluh Agama Islam menyediakan dirinya untuk turut memikirkan dan memecahkan persoalan-persoalan yang dihadapi masyarakat, baik secara pribadi, keluarga maupun sebagai anggota masyarakat umum. Fungsi Advokatif, ialah Penyuluh Agama Islam
\end{abstract}

${ }^{5}$ Dokumen KMA No. 516 Tahun 2003 tentang Petunjuk Teknis Pelaksanaan Jabatan Penyuluh Fungsional 
memiliki tanggung jawab moral dan sosial untuk melakukan kegiatan pembelaan terhadap umat/masyarakat dari berbagai ancaman, gangguan, hambatan dan tantangan yang merugikan aqidah, mengganggu ibadah dan merusak akhlak"

Penyuluh Agama Islam memiliki peranan yang cukup strategis. Penyuluh Agama mengemban berbagai berfungsi seperti pendakwah, pembimbing, penerang, dan berperan serta dalam pembangunan dengan pendekatan bahasa agama. Penyuluh agama Islam dituntut tanggap terhadap persoalan umat, baik dalam hal amaliah agama dan juga problem kehidupan (ekonomi) yang dirasakan masyarakat.

Muallaf adalah bagian dari masyarakat yang merupakan warga binaan dari para penyuluh agama agar menjadi kokoh imanya, dan semangat dalam beramal ibadahnya. Muallaf dalam pengertian bahasa adalah orang yang dicondongkan hatinya dengan perbuatan baik dan kecintaan. Dalam pengertian syariah, muallaf adalah orang-orang yang diikat hatinya untuk mencondongkan mereka pada Islam, atau untuk mengokohkan mereka pada Islam, atau untuk menghilangkan bahaya mereka dari kaum muslimin, atau untuk menolong mereka atas musuh mereka, dan yang semisal itu?

Dalam kesehariannya, Penyuluh Agama menjadi teman diskusi siapa saja untuk memecahkan dan menyelesaikan dengan nasehatnya. Penyuluh Agama sebagai tokoh sentral bertindak sebagai panutan dalam hal agama dan keumatan termasuk permasalahan muallaf agar pemberdayaan muallaf dapat diwujudkan dengan tindakan riil.

${ }^{6}$ Dokumen KMA No 79 Tahun 1985 tentang Penguatan Produktifitas Kerja Penyuluh

${ }^{7}$ Yusuf Qordlowi, Fiqih Zakat. (Bandung: Litera Antar Nusa, 2015), h. 57 
Sebahagian orang berpandangan bahwa muallaf itu adalah orang yang baru saja masuk Islam dan padanya berhak untuk mendapatkan santunan zakat. Para fuqaha berbeda pendapat terkait hak zakat bagi muallaf telah gugur sekarang. Ulama Hanafiyah, berpendapat hak zakat itu telah gugur setelah Islam kuat dan tersebar luas. Sedangkan jumhur ulama, yaitu ulama Malikiyah, Syafi'iyah, dan Hanabilah, berpendapat hak zakat bagi muallaf tidak gugur. Sementara, kalangan jumhur ulama ini juga ada pendapat bahwa hak zakat muallaf telah terputus (munqathi'), yakni tak diberikan lagi sekarang tapi kalau ada kebutuhan untuk mengikat hati mereka, zakat diberikan lagi ${ }^{8}$.

Dari beberapa pendapat, benang merah dari pengertian muallaf yaitu orang yang baru masuk Islam dalam beberapa tahun dan masih awam dalam Ilmu agama Islam. Muallaf adalah sesorang yang baru mengenal Islam, dan masuk Islam dan selalu ingin mengetahui Islam. Muallaf yang Islam karena Hidayah Allah Ta'ala mereka akan selalu benar-benar mendalami ajaran Islam secara intensif, sedangkan para Muallaf yang Islamnya dikarenakan Keturunan biasanya hanya sekedar mengikuti pasangannya, mereka biasanya mereka lebih tidak peka terhadap Islam itu sendiri,

Maka dari itu perlu lembaga da'wah untuk memfasilitasi pembinaan para muallaf agar mereka lebih paham, kokoh aqidah dan tidak kembali lagi ke agama semula.

\footnotetext{
${ }^{8}$ Wahbah Zuhaili, Tafsir Al-Munir Aqidah, Syariah, Manhaj, Pengertian Muallaf, 3/298-299. $36 / 13$, 23/319, di akses https://www.google.co.id/search?q=Wahbah+Zuhaili, $+3 / 298$ tanggal 11 Pebruari 2020 $299 ;+36 / 13,+23 / 319$
} 
Rosidin, Widodo, \& Siti Aminah: Strategi Penyuluh Agama Dalam Pemberdayaan Muallaf Kecamatan Turi Kabupaten Sleman

\section{Pemberdayaan Muallaf}

Pemberdayaan berkembang dari realitas individu atau masyarakat yang tidak berdaya atau pihak yang lemah (powerless) baik dalam aspek pengetahuan, pengalaman, sikap, ketrampilan, modal usaha, networking, semangat, kerja keras, ketekunan dan aspek lainnya. Kelemahan itu mengakibatkan ketergantungan, ketidakberdayaan dan kemiskinan. ${ }^{9}$

Pemberdayaan juga merupakan proses memberikan daya (power) kepada pihak yang lemah (powerless), dan mengurangi kekuasaan (disempowered) kepada pihak yang terlalu berkuasa (powerfull) agar terjadi keseimbangan. ${ }^{10}$

Dalam hal ini, pemberdayaan mualaf yang dilakukan penyuluh Agama Islam meliputi pemberdayaan ekonomi, penguatan aqidah, akhlak, dan sosial melalui berbagai kegiatan yang melibatkan para mualaf di Kecamatan Turi.

\section{METODE PENELITIAN}

Data kajian ini merupakan hasil penelitian dengan pendekatan kualitatif. Penelitian kualitatif tujuannya memahami fenomena apa yang dialami oleh subjek penelitian secara holistic, deskripsi dalam bentuk katakata dan bahasa, pada suatu konteks khusus yang alamiah dan dengan memanfaatkan berbagai metode alamiah. ${ }^{11}$ Subyek dalam kajian ini adalah mualaf Turi yang sempat di mintai informasinya saat pengumpulan data.

${ }^{9}$ Rosidin, Indeks Peran Penyuluh Agama dalam Membina Kehidupan Beragama Keluarga Majelis Taklim di Kabupaten Sragen, Jurnal SMART, Vol. 3 No. 1 Juni 2017, (Semarang: Balai Penelitian dan Pengembangan Agama Semarang, 2017), h.180

${ }^{10}$ M. Anwas, Oos, 2014. Pemberdayaan Masyarakat Di Era Global. (Jakarta: Alfabeta, CV, 2014), h.49

${ }^{11}$ Rosidin dan Nurul Aeni, Indeks Pemahaman Agama Dalam Konteks Kebangsaan: Studi Kasus Pada Organisasi Rohis SMA Negeri 1 Sragen, dalam Jurnal Pendidikan \& 
Pengambilan data dilakukan dua tahap mulai bulan September sampai Desember 2018. Pertama, tahap pendahuluan dilakukan pada tanggal 2-8 September 2018 untuk menentukan lokasi, permasalahan dan tujuan penelitian. Pada tahap ini dilakukan penelusuran informasi melaui Kantor Kementerian Agama hingga KUA dan pemerintah Kabupaten Sleman. Kedua, tahap pengumpulan data lapangan dilakukan pada tanggal 01-15 Oktober 2018. Pada tahap ini mengumpulkan data yang relevan untuk menjawab pertanyaan penelitian. Sumber informasi berasal dari beberapa wakil Mualaf di Kecamatan Turi.

Analisis data yang digunakan dalam kajian ini analisis kualitatif. Analisis ini melibatkan data dalam bentuk verbal sehingga perlu dilakukan pengelompokan dan pengkategorian sehingga konstruksi data dapat menjawab penelitian. ${ }^{12}$ Analisis difokuskan pada penginterpretasian peran penyuluh Agama dalam pemberdayaan Muallaf di Kecamatan Turi Sleman.

\section{PEMBAHASAN}

\section{Setting Wilayah Kecamatan Turi}

Kecamatan Turi berbatasan dengan Kecamatan Tempel dan Kecamatan Pakem, lebih tepatnya berada di kaki gunung Merapi bagian selatan. Daerah ini merupakan daerah pinggiran dikabupaten Sleman utara. Masyarakat Turi sebagian besar sebagai petani pekebun dengan ikon Sleman sebagai daerah penghasil Salak Pondoh di Sleman.

Kebudayaan, Vol. 2 No. 2Desember 2017. Jakarta: Badan Penelitian dan Pengembangan Kementerian Pendidikan dan Kebudayaan, 2017), h. 140

${ }^{12}$ Rosidin dan Nurul Aeni, Indeks Pemahaman Agama Dalam Konteks Kebangsaan: Studi Kasus Pada Organisasi Rohis SMA Negeri 1 Sragen, Jurnal Pendidikan \& Kebudayaan, Vol. 2 No. 2 Desember 2017. (Jakarta: Badan Penelitian dan Pengembangan Kementerian Pendidikan dan Kebudayaan, 2017), h. 140 
Rosidin, Widodo, \& Siti Aminah: Strategi Penyuluh Agama Dalam Pemberdayaan Muallaf Kecamatan Turi Kabupaten Sleman

Data Keagamaan Berdasarkan data monografi yang di dapat menunjukkan bahwa jumlah penduduk Kecamatan Turi menurut jenis kelamin adalah seimbang sebagai berikut:

Tabel 1. Penduduk Kecamatan Turi menurut jenis Kelamin

\begin{tabular}{ccccc}
\hline \multirow{2}{*}{ No } & Nama Desa & \multicolumn{3}{c}{ Jumlah Penduduk } \\
\cline { 3 - 5 } & Laki-laki & Perempuan & Jumlah \\
\hline 1 & Bangunkerto & 4.229 & 4.204 & 8.433 \\
\hline 2 & Donokerto & 4.389 & 4.510 & 8.899 \\
\hline 3 & Wonokerto & 4.767 & 4.680 & 9.447 \\
\hline 4 & Girikerto & 3.773 & 3.809 & 7.582 \\
\hline & Jumlah & 17.158 & 17.203 & 34.361 \\
\hline
\end{tabular}

Sumber: BPS, $2018^{13}$

Penduduk beragama Islam sebesar itu, saat ini di tangani oleh 3 orang Penyuluh Agama Islam Fungsional (PAIF) dan 15 orang Penyuluh Agama Honorer (PAH). Organisasi Keagamaan yang eksis membimbing masyarakat di wilayah Kecamatan Turi diantaranya: Persyarikatan Muhammadiyah, Nahdlatul Ulama, Majelis Tafsir Al Qur'an, LDII, FUI, IPHI, BKRMI, DMI, LPPA dan BADKO TPA. ${ }^{14}$ Diantara penduduk muslim itu, terdapat sekitar 86 orang Mualaf yang tersebar di 4 desa yaitu desa Girikerto 44 orang, Wonokerto 22 orang, Donokerto 15 orang dan ada 5 orang mualaf di desa Bangunkerto. Mualaf itu setiap bulannya mengikuti kegiatan pembinaan yang di lakukan para petugas dari Kementerian Agama. ${ }^{15}$

${ }^{13}$ BPS Kabupaten Sleman, Kecamatan Turi Dalam Angka Tahun 2017, (Sleman: PT. Solo Grafika Utama, 2018), h. 18

${ }^{14}$ Wawancara dengan An, Kepala KUA Kec. Turi, tanggal 3 Oktober 2018

${ }^{15}$ Wawancara dengan PG, Ketua Muallaf Kecamatan Turi, tanggal 2 Oktober 2018 
Rosidin, Widodo, \& Siti Aminah: Strategi Penyuluh Agama Dalam Pemberdayaan Muallaf Kecamatan Turi Kabupaten Sleman

\section{Fungsi Penyuluh Agama Islam}

Penyuluh agama memiliki peran yang sangat penting dan strategis dalam melaksanakan tugas Kementerian Agama. Mereka memiliki tugas melaksanakan bimbingan dan penyuluhan agama, juga memberikan penerangan dan pencerahan dan motivasi pelaksanaan program-program pembangunan melalui bahasa agama. ${ }^{16}$

Problematika dakwah dari sisi pelaksana dakwah (dai, muballigh, Penyuluh), adalah aktivitas dakwah belum semua mampu menterjemahkan persoalan umat secara rinci. Sehingga belum dapat dicarikan jalan keluarnya dalam konteks dakwah Islam. Namun, betapapun rendahnya kualitas keilmuan dan kemampuan penyampaian seorang da'i , muballigh, ataupun penyuluh agama, umumnya umat Islam (obyek dakwah) menyadari bahwa ia mereka tetap merupakan sosok perhatian dari gerakan dakwah. Penyuluh Agama Islam merupakan agen perubahan (agent of change), pemimpin (leader) bahkan pemimpin ummat (sayyidul qaum). Penyuluh Agama Islam merupakan unsur yang dominan dalam pelaksanaan dakwah/kepenyuluah agama, bahkan ia merupakan pemegang kunci terpenting terhadap sukses atau tidaknya pelaksanaan dakwah agama

Penyuluh agama sebagai figure central kepenyuluhan dituntut mampu merealisasikan kegiatan penyuluhan dalam masyarakat. Tanpa realisasi penyuluh agama amar makruf nahi mungkar yang dilakukan oleh umat dengan kualitas terbaik (khaira ummatin), maka ummatan wahidatan menjadi tidak mungkin. Maka penyuluhan agama menjadi bagian esensial

\footnotetext{
${ }^{16}$ FORSIPAIF dan POKJALUH DIY, Panduan Pembuatan Instrumen Administrasi Penyuluhan Agama, (Yogyakarta: Kanwil Kemenag DIY, 2010), h. vii
} 
Rosidin, Widodo, \& Siti Aminah: Strategi Penyuluh Agama Dalam Pemberdayaan Muallaf Kecamatan Turi Kabupaten Sleman

yang tidak terpisahkan dengan ihtiar mewujudkan tatanan masyarakat yang ummatan wahidatan yang adil dalam ridha Allah "baldatun toyyibatun wa rabbun ghofur".

\section{Strategi Penyuluh Agama dalam Memberdayakan Muallaf}

Harapan besar masyarakat pada umumnya seolah-olah dipikulkan di pundak para penyuluh agama untuk memecahkan berbagai macam problematika umat yang sangat komplek dan terus berkembang seiring dengan perjalannan waktu, maka penyuluh agama dituntut harus meningkatkan kompetensi diri, baik keilmuan maupun menejerial.

Permasalahan terus berkembang dan sangat komplek baik persoalan pemahaman agama dengan beragam pemahaman yang kadang terjadi sumber pergesekan, dan juga problem ekonomi yang juga tidak kalah pentingnya yang rentan menimbulkan problema baru. Hal itu tidak hanya terjadi di wilayah lain tetapi juga terasa di wilayah Turi khususnya di kalangan muallaf.

Tantangan demi tantangan dengan tingkat kompleksitasnya yang terjadi di tengah-tengah masyarakat tentu ini menjadi lahan bagi para penyuluh Agama untuk menguji tentang kualitas dirinya dalam mengatasi problematika umat. Sebagai salah satu bagian dari tantangan penyuluh agama Islam yakni bagaimana peran dan fungsinya dalam pemberdayaan terhadap para muallaf. Permasalahan muallaf memang tidak begitu mencuat, bahkan cenderung terabaikan bila dibandingkan dengan permasalahan ekonomi, politik, pendidikan, teknologi dan lain sebagainya. Kebutuhan para muallaf bukan hanya sekedar dibimbing untuk ibadah ritual, tetapi penguatan hati dengan aqidah yang kokoh, pendalaman pengetahuan agama yang benar, penguatan ekonomi, dan memberikan 
Rosidin, Widodo, \& Siti Aminah: Strategi Penyuluh Agama Dalam Pemberdayaan Muallaf Kecamatan Turi Kabupaten Sleman

perlindungan support mental disaat menghadapi berbagai macam tekanantekanan secara fisik dan psikologis.

Tidak sedikit dari kalangan muallaf ingin mencari kedamaian hati dengan hidayah Islam melalui berbagai jalan berliku yang ia tempuh untuk mendapatkan hidayah kebenaran. Saat ini berbagai lembaga atau yayasan bergerak megurus muallaf ini. Lembaga ini memberi pelatihan ilmu agama Islam seperti Al-Qur'an dan Hadis guna megokohkan iman para muallaf terhadap kebenaran Islam. Pelatihan wirausaha dan pemberian dana kepada Muallaf juga sangat penting supaya ke depan muallaf berubah dari penerima zakat menjadi pemberi zakat. Tetapi lembaga tersebut belum merambah ke lingkungan pinggiran termasuk diwilayah Kecamatan Turi atau di sebahagian wilayah Kabupaten Sleman utamanya daerah pinggiran. Kondisi seperti ini yang mengugah semangat para penyuluh Agama Islam untuk memulai memberikan pendampingan kepada para muallaf terutama dalam pendampingan penguatan agama dan juga ekonominya.

Kondisi riil di masyarakat banyak kalangan para muallaf yang terabaikan dari berbagai aspek, baik pendalaman pengetahuan pemahaman agama, penguatan ekonomi dan pembelaan dari berbagai ancaman, intimidasi dan juga gangguan. Dalam pembahasan ini difokuskan pada pemberdayaan muallaf di bidang penguatan aqidah, ibadah dan penguatan ekonomi, dan khususnya di wilayah Kecamatan Turi. Problem secara umum muallaf di wilayah Kecamatan Turi yakni persoalan pemahaman pengetahuan agama (aqidah dan ibadah) dan ekonomi rumah tangga.

Penyuluh Agama memiliki tanggung jawab mendorong atau memotivasi kaum muslim melindungi para muallaf baik moril maupun materil. Karena, apabila seseorang muallaf kehidupannya semakin 
Rosidin, Widodo, \& Siti Aminah: Strategi Penyuluh Agama Dalam Pemberdayaan Muallaf Kecamatan Turi Kabupaten Sleman

menderita dikhawatirkkan berdampak buruk terhadap pelaksanaan ajaran Islam.

Berdasarkan hasil wawancara dengan seorang muallaf di Turi ada beberapa muallaf yang terus mengalami tekanan-tekanan dari lingkungannya baik dari keluarga dan juga masyarakatnya yang mayoritas masih non muslim. Mereka para muallaf ada yang belum bebas menjalankan perintah agamanya (keyakinan Islam), karena masih dibayang-bayangi dengan orang-orang sekitar yang tidak menghendaki dia berubah keyakinan. Banyak sekali keluhan dari para muallaf yang merasa belum bebas menjalankan perintah agama dan juga untuk mengembangkan ketrampilannya yang dia miliki, seperti merintis usaha ekonomi produktif yang bersifat profit. ${ }^{17}$

Perasaan para muallaf yang belum merdeka akan berpengaruh terhadap pengembangan wawasan keilmuan dan juga pengembangan ketrampilannya. Untuk itu muallaf sebagaimana dalam pengertian orang yang masih lemah keimanannya karena baru dicondongkan kepada Islam atau baru masuk Islam, maka perlu adanya penguatan-penguatan kepadanya, sehingga mereka tetap istiqomah dalam menjaga imannya.

Beberapa orang muallaf di wilayah Kecamatan Turi yang akhirnya kembali murtad atau kembali kepada keyakinan semula, dikarenakan tidak kuat menghadapi kenyataan persoalan hidup yang melanda dirinya berupa tekanan-tekanan dari keluarga dan komunitasny. ${ }^{18}$ Dengan demikian peran Penyuluh Agama Islam diharapkan mampu

${ }^{17}$ Interview dengan Yunanti, Muallaf, tanggal 5 Nopember 2018

${ }^{18}$ Interview dengan Eni Ernawati, Petra Nugrahaningsih, Stevani Sulisstiyani, 14 Desember 2018

Al Qalam: Jurnal Ilmiah Keagamaan dan Kemasyarakatan Vol. 14, No. 1, Januari-Juni 2020 
Rosidin, Widodo, \& Siti Aminah: Strategi Penyuluh Agama Dalam Pemberdayaan Muallaf Kecamatan Turi Kabupaten Sleman

memberdayakan para muallaf agar lebih kuat hatinya dalam menjaga imannya.

Untuk memberdayakan muallaf di Kecamatan Turi, perlu perhatian serius dan kerja keras dari seluruh masyarakat muslim dan rencanarencana kegiatan yang tepat. Pelaku yang semestinya terlibat dalam kegiatan pemberdayaan ini adalah Penyuluh Agama Islam Fungsional (PAIF) dan Penyuluh Agama Honorer (PAH), Ormas keagamaan Islam, lembaga dakwah, dan para tokoh agama Islam. Maka posisi penyuluh agama dalam pemberdayaan muallaf di Kecamatan Turi yakni mendorong kepada seluruh muallaf untuk mempelajari ajaran agamanya, kepada para mubaligh dan mubalighah diwilayah Kecamatan Turi untuk peduli kepada nasib muallaf baik dalam pendalaman pemahaman terhadap agama dan juga kebutuhan ekonominya.

\section{Bentuk dan Implikasi Pemberdayaan Mualaf}

Untuk memberikan gambaran yang lebih jelas, perlu dijelaskan pengertian kata Berdaya artinya berkekuatan, pemberdayaan bermakna membuat lebih berdaya/berkekuatan. ${ }^{19}$ Selanjutnya, berdasarkan pengertian di atas, dapat dikatakan bahwa lebih berdaya dimaknai mampu meningkatkan kualitas proses dan hasil kegiatan. Adapun cara yang digunakan penulis untuk memberdayakan muallaf tersebut adalah dengan melakukan kegiatan-kegiatan yang sistematis.

Bentuk-bentuk program pemberdayaan muallaf di wilayah Kecamatan Turi yang sudah berjalan adalah sebagai berikut:

${ }^{19}$ Pusat Bahasa. Kamus Besar Bahasa Indonesia. (Jakarta: Pusat Bahasa Depdiknas RI, 2000), h. 241-242 
Rosidin, Widodo, \& Siti Aminah: Strategi Penyuluh Agama Dalam Pemberdayaan Muallaf Kecamatan Turi Kabupaten Sleman

\section{Pembentukan Forum Silaturrahmi Muallaf Kecamatan Turi.}

Pendataan muallaf Kecamatan Turi sudah dilakukan sejak tahun 2009 yang dilakukan oleh Penyuluh Agama Islam. Pada tahun 2009 kegiatan pembinaan mulai dilakukan oleh Penyuluh Agama dengan nama Jama'ah Al Muhtadin. Pendampingan keagamaan terus berjalan dengan fokus pada penguatan aqidah. Hal ni sesuai peran dan fungsi penyuluh agama fungsi Informatif dan Edukati. $f^{20}$

Seiring berjalannya waktu pada tahun 2013 dibentuklah lembaga yang resmi dengan nama Forum Komunikasi Muallaf Kecamatan Turi kemudian pada awal tahun 2014 diubah namanya menjadi Forum Silaturrahmi Muallaf Kecamatan Turi. Setelah nama lembaga terbentuk serta kepengurusan, kemudian dilembagakan secara resmi. Pada tahun 2014 lembaga tersebut disyahkan oleh pihak pemerintah Kecamatan Turi dan kepengurusan diketahui oleh Camat Turi. Dengan kelembagaan ini organisasi muallaf Kecamatan Turi resmi terbentuk, sehingga dengan kelembagaan tersebut akhirnya bisa menjalin kerjasama dengan lintas sektoral yaitu dengan organisasi keagamaan seperti Muhammadiyah, Nahdlatul Ulama, Forum Ukhuwah Islamiyah, IPHI, MUI dan lainlainnya.

Manfaat dibentuknya organisasi Forum Silaturrahmi Muallaf Kecamatan Turi maka secara otomatis lembaga ini dapat mengakses sumber- sumber pendanaan ke berbagai pihak, baik kegiatan keorganisasian maupun pemberdayaan anggotanya. Penyuluh Agama melaksanakan fungsi konsultatif yang pada akhirnya ada pembentukan forum atas prakarsa Penyuluh Agama.

\footnotetext{
${ }^{20}$ Interview dengan Anshari, Kepala KUA Turi, tanggal 6 September 2018
} 
Rosidin, Widodo, \& Siti Aminah: Strategi Penyuluh Agama Dalam Pemberdayaan Muallaf Kecamatan Turi Kabupaten Sleman

Penyuluh Agama Islam dalam memprakarsai terbentuknya organisasi tersebut adalah sebagai wadah untuk menampung berbagai keluhan dari para muallaf yang masih mendapat tekanan - tekanan baik dari lingkungan anggota keluarga maupun komunitas sebelumnya. Hal ini mendukung fungsi ketugasan Penyuluh memiliki yaitu fungsi.

\section{Penguatan Ke Imanan dan Pengamalan Ajaran Islam}

Penyuluh Agama memiliki fungsi Informatif dan Edukatif. Upaya penguatan aqidah dan pengamalan ajaran agama sesuai syariat untuk para muallaf dilakukan penyuluh agama Islam Fungsional dan penyuluh Agama Honorer secara sinergi. ${ }^{21}$ Adapun materi penyuluhan antara lain:

Materi Aqidah. Materi ini mencakup masalah-masalah yang erat hubungannya dengan rukun Iman. Pembahasannya tidak hanya tertuju pada masalah-masalah yang wajib diimani, akan tetapi masalah-masalah yang dilarang sebagai lawannya, seperti Syirik, ingkar dengan adanya Tuhan dan sebagainya. Materi Syari'ah, berhubungan erat dengan amal lahir (nyata) dalam rangka mentaati semua hukum Allah dalam mengatur hubungan antara manusia dengan Tuhannya, pergaulan hidup sesama manusia dan manusia dengan alam sekitar.

Materi Akhlak, dimana akhlak atau sistem perilaku ini terjadi melalui suatu konsep atau seperangkat pengertian tentang apa dan bagaimana sebaiknya Akhlak itu harus terwujud. Penyuluh mengerti dan menguasai materi yang akan disajikan, sebab Akhlak sebagai penyempurna keimanan dan keislaman seseorang.

Materi Baca Tulis al-Qur`an, dimana Penyuluh Agama Islam di tuntut mengetahui bahwa Al-Qur'an adalah Wahyu Allah swt, pedoman

${ }^{21}$ Interview dengan Lilis Widyasih, PAH, tanggal 8 Oktober 2018 
Rosidin, Widodo, \& Siti Aminah: Strategi Penyuluh Agama Dalam Pemberdayaan Muallaf Kecamatan Turi Kabupaten Sleman

bagi hidup dan kehidupan manusia, terutama umat Islam agar bahagia di dunia dan akhirat. Dalam hal ini Penyuluh Agama Islam perlu memahami dan sekaligus dapat mengajarkan Al-Qur'an dengan baik dan benar.

Konsep diatas sangat ideal maka dalam tataran praktis di masyarakat konsep tersebut disederhanakan dan disesuaikan dengan kondisi muallaf karena para muallaf memiliki latar belakang pendidikan yang berbeda- beda. Menjadi muallaf juga dengan motivasi yang berbedabeda misalnya menjadi muallaf karena hidayah taufik dari Allah, karena ikatan perkawinan, dan lain-lain sebagainya.

Kegiatan pembinaan keimanan muallaf di Kecamatan Turi terbagi dalam beberapa agenda kegiatan yaitu; pertemuan rutin mingguan, dan juga pertemuan bulanan dalam suatu kegiatan yang terjadwal. Kegiatan pembinaan keagamaan terhadap muallaf penyuluh agama Fungsional berkoordinasi dan bekerjasama dengan para penyuluh non PNS, bahkan kita mengangkat penyuluh Non PNS dari kalangan muallaf. Kendala dalam program penguatan keimanan karena ada sebagian para muallaf masih belum bisa leluasa mengikuti kegiatan kajian, karena faktor eksternal yakni tekanan secara psikologis dari lingkungannya.

\section{Pemberdayaan Ekonomi Kepada Para Muallaf Katagori Dhuafa'}

Potret muallaf Turi sebagian besar dari kalangan dhuafa' atau masyarakat ekonomi lemah dan berpendidikan rendah. Kondisi muallaf ini berpengaruh pada keperibadiannya. Penyuluh agama mestinya menyadari bahwa telah melekat pada dirinya sebagai konsultan atau memiliki tugas fungsi Konsultatif, sehingga menyediakan diri dan turut memikirkan serta memecahkan persoalan-persoalan yang dihadapi masyarakat, baik pribadi, 
Rosidin, Widodo, \& Siti Aminah: Strategi Penyuluh Agama Dalam Pemberdayaan Muallaf Kecamatan Turi Kabupaten Sleman

keluarga maupun masyarakat umum. Problem mayoritas muallaf Turi adalah masalah ekonomi yang identik dengan kemiskinan. ${ }^{22}$

Beberapa kesulitan yang melanda muallaf karena kefakirannya yaitu terjerat hutang dengan orang-orang non Muslim, dan hal ini menjadi tekanan secara psikologis bagi para muallaf. Sebagai contoh ibu-ibu muallaf terjerat hutang dengan organisasi WK (organisasi Wanita Katolik), sementara hutang berbunga nilai hutang semakin bertambah besar seiring dengan bertambahnya waktu. Keluhan para muallaf yang disampaikan kepada penyuluh agama dalam acara koordinasi dan konsultasi, sebagai berikut:

Difitnah mencuri salak, kejadiannya ketika dia pergi ke kebon salak pondoh miliknya dengan membawa keranjang untuk memetik salak pondoh, dan keranjang tersebut sudah terisi salak pondoh miliknya, kemudian ditaruh dipinggir kebun. Tiba-tiba ada seseorang sudah mengintai sembunyi-sembunyi kemudian memindahkan keranjang berisi salak tersebut ke kebun orang katolik tetangganya kemudian setelah itu diteriakin malingmaling. Saudara Tanto ini tidak bisa berbuat banyak, hanya pasrah, kemudian diselesaikan ke dukuh setempat. Kondisi inilah yang menjadikan efek traumatik dan pembunuhan karakter oleh orang - orang yang dengki kepadanya. Akhir kisah persoalan ini terselesaikan dengan damai, tetapi dampak pencemaran nama baik itu menjadikan yang bersangkutan menjadi minder. ${ }^{23}$

Pembuat Tempe.saya muallaf kesehariannya membuat tempe secara manual, dengan jumlah pelanggan yang cukup, sehingga dari usahanya bisa untuk menopang biaya hidupnya. Dari usahanya peminat dan pelanggan tempenya semakin banyak, maka ibu ini menambah jumlah produksinya. Tiba - tiba orang non Muslim yang ada dekatnya juga memproduksi tempe dengan modal besar dengan peralatan yang modern, jumlah produksi yang besar dan merampas pelanggan tempe Ibu Budinah. Akhirnya ibu Budinah usaha tempenya bangkrut, ujung- ujungnya gulung tikar, berhenti tidak produksi karena modal habis. Ibu ini hanya bisa menangis meratapi nasib. Setelah Ibu Budinah tidak produksi tempe ternyata orang non itu juga berhenti usaha tempenya, hal ini

\footnotetext{
${ }^{22}$ Wawancara dengan Is, Pengurus BAZNAS Sleman, tanggal 21 Desember 2018

${ }^{23}$ Wawancara Ta dan Istri, keluarga Muallaf, tanggal 6 Oktober 2018
} 
usaha mereka untuk menghentikan dan mematikan usaha para muallaf. $^{24}$

Pengkrajin Kripik Pegagan. Kisahnya hampir sama seperti Ibu Budinah, hanya perbedaan ibu Budinah berhenti tetapi Ibu Suyantinah ini tetap melanjutkan usahanya. Alhamdulillah atas taqdir Allah SWT Ibu Suyantinah menikmati tantangan ini dengan kesabaran dan akhirnya pelanggan - pelanggannya kembali dan mencarinya. Ia mendapat tekanan dengan teror psikologis dengan kalimat "Awas kamu itu hanya sedikit jangan macam-macam". Ia menceritakan sambil menangis karena memang jumlah muslim muallaf di daerah itu hanya $40 \%$ dari jumlah penduduk dikampung tempat tinggalnya, sejarahnya sebelumnya $100 \%$ non Muslim dan sekarang yang menjadi muallaf sudah $40 \%$. Dan masih banyak kisah-kisah suka dan duka yang dialami oleh para muallaf. ${ }^{25}$

Keluhan dari para muallaf telah memotivasi penyuluh agama dan menjadikan tertantang untuk mencarikan berbagai solusi dari berbagai problem yang dirasakan oleh para muallaf. Peran dan Fungsi konsultatif bahwa penyuluh menjadi pendengar selanjutnya mencari pemecahan dari berbagai problem tersebut.

Disamping itu sebagai upaya optimalisi peran dan fungsi Advokatif, penuluh agama berupaya mengatasi berbagai problem perekonomian muallaf dengan membangun jejaring dengan Lembaga Donor dan mengadakan kegiatan syiar diantaranya; Kerjasama dengan BAZNAS Kabupaten Sleman dan BAZ Kecamatan Turi.

Penyuluh Agama bersama Pengurus Forum Silaturrahmi Muallaf menyusun sebuah proposal projek kegiatan pemberdayaan ekonomi produktif untuk para muallaf. Adapun pemberdayaan ekonomi produktif tersebut difokuskan pada pemberian dana stimulan untuk usaha mandiri dan juga penguatan modal usaha yang sudah dijalankan oleh para muallaf.

\footnotetext{
${ }^{24}$ Wawancara dengan Ibu Bu, anggota forum Muallaf, tanggal 13 Oktober 2018.

${ }^{25}$ Wawancara dengan Su, tanggal 10 Oktober 2018
} 
Pada hari Selasa, 29 April 2014, Penyuluh Agama dan Pengurus Forum Muallaf Turi mengajukan proposal projek ke BAZNAS Kabupaten Sleman. Proposal tersebut mendapat respon dengan dikucurkan dana bantuan pendampingan pemberdayaan ekonomi muallaf Turi sebesar $\mathrm{Rp}$ 27.900 .000 (dua puluh tujuh juta sembilan ratus ribu rupiah). Dana tersebut kemudian digunakan untuk penguatan modal usaha yang bersifat stimulan yaitu untuk kegiatan; Sumbangan Stimulan usaha Perbengkelan Mobil, Peternakan Kambing Gembel, dan Etawa,Kegiatan Warungan (Kaki Lima) Soto Bakso, Home Industri Tempe, Pengrajin Kripik Pegagan, Warungan (ratengan) membuat gorengan, Pertanian lombok, Perikanan lele dan Kios sembako. ${ }^{26}$

Adapun Sumber Dana BAZ Kecamatan Turi yang dipergunakan untuk muallaf ditasyarufkan untuk membiayai anak-anak muallaf yang tidak mampu biaya sekolah, kesehatan, usaha produktif, untuk biaya sidang pernikahan keluarga muallaf dhuafa yang dibawah umur dan santunan - santunan lainya. Disamping itu juga dana BAZ Kecamatan juga digunakan untuk membiayai kegiatan muallaf yang merupakan kegiatan kajian rutin bulanan.

\section{Gebyar Muallaf Turi}

Gebyar Muallaf Turi pernah diadakan pada tahun 2015. Kegiatan diadakan dalam rangka syiar dakwah Islam untuk memberikan suport kepada para muallaf. Gebyar ini berawal ketika para muallaf menyampaikan keluhan kepada penyuluh agama dalam acara pengajian

${ }^{26}$ Wawancara dengan Lilis Wedyahwati, Penyuluh Agama Honorer, tanggal 13 Oktober 2018 
Rosidin, Widodo, \& Siti Aminah: Strategi Penyuluh Agama Dalam Pemberdayaan Muallaf Kecamatan Turi Kabupaten Sleman

dan koordinasi. Di antara keluhan yang disampaikan adalah intimidasi yang bersifat verbal dengan ungkapan "kamu itu sedikit tidak usah macammacam". Keluhan muallaf tersebut mendapat respon dari penyuluh agama kemudian dibahas dalam rapat Pokjaluh Rayon Tengah (penyuluh Kecamatan Tempel, Kecamatan Ngaglik, Kecamatan Sleman, Kecamatan Mlati, dan Penyuluh Kecamatan Sleman).

Sinergi Penyuluhan Agama Islam Fungsional Rayon Tengah, Penyuluh non PNS bersama dengan Ormas Kecamatan dan MUSPIKA Kecamatan Turi mengadakan Gebyar Muallaf Turi 2015. Kegiatan Gebyar Muallaf inidilaksanakan pada hari Selasa tanggal 28 April 2015 dengan berbagai agenda, diantaranya: Pengukuhan Pengurus Forum Silaturrahim Muallaf Kecamatan Turi oleh Camat Turi; Khitan Masal bagi putra muallaf dan anak -anak fakir miskin di wilayah Kecamatan Turi sebanyak 58 peserta dengan masing mendapat uang Saku Rp 100.000,- Sarung dan kopiah dengan tenaga eksekutor dari RS PKU Muhammadiyah Pakem dengan biaya per peserta Rp 100.000,- semua biaya ditanggung oleh Lumbung Zakat Indonesia; Pemeriksaan dan Pengobatan Gratis kepada para muallaf dan warga sekitar bekerjasama dengan RS PKU Muhammadiyah Pakem; Pemberian Santunan Unggas Menthok dan Bekatul (200 ekor dan 1 Ton Bekatul) kepada seratus (100) muallaf Turi masing - masing sepasang menthok ( 2 ekor), penyerahan secara simbolis dilakukan oleh Bupati Sleman Drs Sri Purnomo MSI, Kepala Kemenag Sleman Drs H Muhammad Lutfi Hamid, M.Ag, dan Ketua BAZNAS Kabupaten Sleman. Dana santunan unggas (menthok dan pakan bekatul) dari BAZNAS Sleman Rp 10.000.000,-, Kantor KEMENAG Sleman Rp 2.000.000,- dan dari Kelompok Kerja Penyuluh Agama Rayon Tengah Rp 1.500.000,-.; Pemberian Pakaian Bagus Pakai untuk para Muallaf; dan 
Rosidin, Widodo, \& Siti Aminah: Strategi Penyuluh Agama Dalam Pemberdayaan Muallaf Kecamatan Turi Kabupaten Sleman

Tabligh Akbar oleh K.H. Sukirman, S.Pd ( Muallaf Mantan Penginjil). Kegiatan Gebyar Muallaf Turi 2015 ini menghabiskan biaya kurang lebih Rp 50.000.000 (lima puluh juta rupiah). Dana tersebut digali dari sumbangan masyarakat, lembaga dakwah, ormas Islam, BANK, Kantor Kementerian Agama Kabupaten Sleman dan BAZNAS Kabupaten Sleman.

Sumbangan Penguatan Modal Usaha dari Rumah Zakat Bandung.

Penyuluh Agama Islam Kecamatan Turi, pada hari ahad tanggal 26 Juli 2015, bertemu dengan salah satu pengurus Rumah Zakat Bandung (Yahya ST Ketua Umum Rumah Zakat Bandung), kemudian berdiskusi tentang problematika dakwah. Salah satu tema tentang dalam pertemuan dan diskusi yaitu tentang muallaf dan segala problematikannya, juga menyinggung kegiatan Gebyar Muallaf Turi 2015 yang dilaksanakan pada bulan April 2015. Dalam diskusi dibahas tentang muallaf dengan pendataan yang valid, menyangkut tentang latar belakang pendidikan, kebutuhan yang mendesak, ketrampilan yang dimiliki, serta pemahaman terhadap ajaran Islam. ${ }^{27}$

Data tentang muallaf termasuk jenis model-model usaha yang dapat dilakukan oleh muallaf, sehingga dengan pemberian modal usaha mereka bisa mandiri, paling tidak terhindar dari jeratan hutang oleh rentenir. Informasi Penyuluh Agama yang didapat dari lapangan hasil investigasi dari bantuan unggas menthok kepada para muallaf sebanyak 200 ekor ternyata pada mati dengan angka kematian sebanyak $75 \%$. Kejadian ini sebenarnya menjadi pukulan bagi penyuluh agama yang telah

${ }^{27}$ Wawancara dengan Yu, anggota Muallaf, tanggal, 6 Oktober 2018 
Rosidin, Widodo, \& Siti Aminah: Strategi Penyuluh Agama Dalam Pemberdayaan Muallaf Kecamatan Turi Kabupaten Sleman

memprakarsai adanya kegiatan BAKSOS dalam acara Gebyar Muallaf tersebut.

Hasil diskusi berlanjut dengan pemberian dana stimulan dari Rumah Zakat Bandung kepada Muallaf Turi. Pada hari Rabu tanggal 29 juli 2015 Rumah Zakat Bandung telah mentransfer uang sumbangan penguatan modal usaha ke Rekening Forum Silaturrahmi Muallaf Turi memberikan bantuan keuangan sebesar Rp 20.000 .000 (dua puluh juta rupiah). Sumbangan untuk penguatan pemberdayaan ekonomi produktif bagi para muallaf di wilayah Kecamatan Turi. Alokasi dana tersebut dipergunakan untuk pemberdayaan ekonomi muallaf yang masuk katagori dhuafa' yaitu dalam bentuk:Dana kegiatan Muallaf 10\%; Pembelian Unggas Menthok sebanyak 70 ekor; Pembelian unggas Ayam Buras sebanyak 80 ekor; Pembelian Ithik Bebek 20 ekor; Pembelian bibit Nila $90 \mathrm{Kg}$; Pembelian Bibit Lele $20 \mathrm{Kg}$; Pengadaan Kandang ayam 70 unit kandang ayam. ${ }^{28}$.

Dana hibah ( bantuan) dari Rumah Zakat ini adalah sebagai stimulan pada tahap pertama dan apabila dengan kegiatan usaha ini mengalami peningkatan, maka nanti akan dievaluasi untuk dikembangkan lebih lanjut. Harapan Rumah Zakat adalah agar predikat muallaf tidak bersifat abadi, bisa hidup mandiri, ibadah bisa khusyuk dan dapat beramal shalih juga menjadi daya tarik bagi sanak saudara yang lainnya yang belum beriman.

Pemberdayaan ekonomi bertujuan untuk membantu mencari solusi menghadapi persoalan yang terkait dengan kebutuhan hidup para muallaf, 2018

${ }^{28}$ FGD (Focus Group Discussion) dengan Kelompok Muallaf, tanggal 5September 
sehingga bias hidup layak dan tidak menjadi beban dan tanggungjawab orang lain. Disamping itu penguatan ekonomi juga dimaksud untuk menjaga imannya sebagaimana sabda Nabi "Kefakiran akan mendekatkan pada kekufuran" untuk itu pemberdayaan muallaf adalah tugas dan tanggungjawab kaum muslimin.

\section{PENUTUP}

Penyuluh Agama Islam memahami kemajemukan masyarakat dalam melakukan berbagai upaya dalam Pemberdayaan Muallaf Kecamatan Turi, antara lain: Pertama, melaksanakan fungsi yang diamanahkan yaitu Informatif dan edukatif, Konsultatif dan Advokatif. Kedua, Program pemberdayaan muallaf Kecamatan Turi yang dilakukan oleh penyuluh agama meliputi dua hal : penguatan kelembagaan dengan membentuk Forum Silaturrahmi Muallaf Kecamatan Turi, penguatan keimanan dan pengamalan ajaran Islam dan Program penguatan ekonomi muallaf.

\section{UCAPAN TERIMA KASIH}

Terima kasih kami haturkan kepada Kepala Balai Penelitian dan Pengembangan Agama Semarang, Kementerian Agama Kabupaten Sleman, KUA Turi, KUA Pakem dan pihak-pihak yang tidak dapat kami sebut satu per satu, atas bantuan data informasi selama penulis melakukan penelitian. 
Rosidin, Widodo, \& Siti Aminah: Strategi Penyuluh Agama Dalam Pemberdayaan Muallaf Kecamatan Turi Kabupaten Sleman

\section{DAFTAR PUSTAKA}

Anwas, M. Oos, Pemberdayaan Masyarakat Di Era Global, Jakarta: CV Alfabeta, 2014

BPS Kabupaten Sleman, Kecamatan Turi Dalam Angka Tahun 2017. Sleman: PT. Solo Grafika Utama, 2018

Departemen Agama, Al Qur'an dan Terjemahan, Jakarta: Departemen Agama, 1990

FORSIPAIF dan POKJALUH DIY, Panduan Pembuatan Instrumen Administrasi Penyuluhan Agama, Yogyakarta: Kanwil Kemenag DIY, 2010

Keppres No. 87 Tahun 1999 tentang Rumpun Jabatan Fungsional Pegawai Negeri Sipil

KMA No. 516 Tahun 2003 tentang Petunjuk Teknis Pelaksanaan Jabatan Penyuluh Fungsional

Pusat Bahasa. 2 Kamus Besar Bahasa Indonesia. Jakarta: Pusat Bahasa Depdiknas RI, 2000

Rosidin, Rosidin, dan Nurul Aeni, Indeks Pemahaman Agama Dalam Konteks Kebangsaan: Studi Kasus Pada Organisasi Rohis SMA Negeri 1 Sragen, Jurnal Pendidikan \& Kebudayaan, Vol. 2 No. 2 Desember 2017, Jakarta: Badan Penelitian dan Pengembangan Kementerian Pendidikan dan Kebudayaan, 2017

Rosidin, Rosidin, Indeks Peran Penyuluh Agama dalam Membina Kehidupan Beragama Keluarga Majelis Taklim di Kabupaten Sragen, Jurnal SMART, Vol. 3 No. 1 Juni 2017, Semarang: Balai Penelitian dan Pengembangan Agama Semarang, 2017

Yusuf Qordlowi, Fiqih Zakat. Bandung: Litera Antar Nusa, 2015 
Rosidin, Widodo, \& Siti Aminah: Strategi Penyuluh Agama Dalam Pemberdayaan Muallaf Kecamatan Turi Kabupaten Sleman

Al Qalam: Jurnal Ilmiah Keagamaan dan Kemasyarakatan Vol. 14, No. 1, Januari-Juni 2020 